\title{
Soil-atmosphere exchange of ammonia in a non-fertilized grassland: measured emission potentials and inferred fluxes
}

\author{
G. R. Wentworth, J. G. Murphy, P. K. Gregoire, C. A. L. Cheyne, A. G. Tevlin, and R. Hems \\ Department of Chemistry, University of Toronto, 80 St. George Street, M5S 3H6, Toronto, Canada
}

Correspondence to: J. G. Murphy (jmurphy@chem.utoronto.ca)

Received: 5 March 2014 - Published in Biogeosciences Discuss.: 27 May 2014

Revised: 12 September 2014 - Accepted: 15 September 2014 - Published: 16 October 2014

\begin{abstract}
A 50-day field study was carried out in a seminatural, non-fertilized grassland in south-western Ontario, Canada during the late summer and early autumn of 2012. The purpose was to explore surface-atmosphere exchange processes of ammonia $\left(\mathrm{NH}_{3}\right)$ with a focus on bi-directional fluxes between the soil and atmosphere. Measurements of soil $\mathrm{pH}$ and ammonium concentration $\left(\left[\mathrm{NH}_{4}^{+}\right]\right)$yielded the first direct quantification of soil emission potential $\left(\Gamma_{\text {soil }}=\left[\mathrm{NH}_{4}^{+}\right] /\left[\mathrm{H}^{+}\right]\right)$for this land type, with values ranging from 35 to 1850 (an average of 290). The soil compensation point, the atmospheric $\mathrm{NH}_{3}$ mixing ratio below which net emission from the soil will occur, exhibited both a seasonal trend and diurnal trend. Higher daytime and August compensation points were attributed to higher soil temperature. Soil-atmosphere fluxes were estimated using $\mathrm{NH}_{3}$ measurements from the Ambient Ion Monitor Ion Chromatograph (AIM-IC) and a simple resistance model. Vegetative effects were ignored due to the short canopy height and significant $\Gamma_{\text {soil }}$. Inferred fluxes were, on average, $2.6 \pm 4.5 \mathrm{ng} \mathrm{m}^{-2} \mathrm{~s}^{-1}$ in August (i.e. net emission) and $-5.8 \pm 3.0 \mathrm{ng} \mathrm{m}^{-2} \mathrm{~s}^{-1}$ in September (i.e. net deposition). These results are in good agreement with the only other bi-directional exchange study in a semi-natural, non-fertilized grassland. A Lagrangian dispersion model (Hybrid Single-Particle Lagrangian Integrated Trajectory - HYSPLIT) was used to calculate air parcel back-trajectories throughout the campaign and revealed that $\mathrm{NH}_{3}$ mixing ratios had no directional bias throughout the campaign, unlike the other atmospheric constituents measured. This implies that soil-atmosphere exchange over a non-fertilized grassland can significantly moderate nearsurface $\mathrm{NH}_{3}$ concentrations. In addition, we provide indirect evidence that dew and fog evaporation can cause a morning increase of $\left[\mathrm{NH}_{3}\right]_{\mathrm{g}}$. Implications of our findings on current
\end{abstract}

$\mathrm{NH}_{3}$ bi-directional exchange modelling efforts are also discussed.

\section{Introduction}

Atmospheric ammonia $\left(\mathrm{NH}_{3(\mathrm{~g})}\right)$ is the most abundant alkaline gas and is important for many biogeochemical and atmospheric processes (Seinfeld and Pandis, 2006). It neutralizes acidic aerosol, leading to increased mass loadings of fine atmospheric particulate matter $\left(\mathrm{PM}_{2.5}\right)$, which reduces visibility and can cause adverse health effects (Pope et al., 2002). In addition, deposition of $\mathrm{NH}_{3}$ and other forms of reactive nitrogen (i.e. $\mathrm{NO}_{\mathrm{x}}, \mathrm{HNO}_{3}$ ) can lead to eutrophication, soil acidification, and loss of biodiversity in sensitive ecosystems (Krupa, 2003). $\mathrm{NH}_{3}$ is primarily emitted through agricultural activities (i.e. fertilization, animal waste) with minor contributions from transportation and chemical industries (Reis et al., 2009).

$\mathrm{NH}_{3(\mathrm{~g})}$ exists in equilibrium with aqueous ammonia $\left(\mathrm{NH}_{3(\mathrm{aq})}\right)$ in surface reservoirs (i.e. apoplastic tissues of plants or soil pore water) that, at least in theory, can be described by the Henry's law constant $\left(K_{\mathrm{H}}\right)$. $\mathrm{NH}_{3(\mathrm{aq})}$ is also in equilibrium with aqueous-phase ammonium $\left(\mathrm{NH}_{4(\mathrm{aq})}^{+}\right)$, governed by the acid dissociation constant $\left(K_{\mathrm{a}}\right)$ of $\mathrm{NH}_{4}^{+}$and the $\mathrm{pH}$ of the solution. The gas-phase concentration above this aqueous phase at thermodynamic equilibrium is known as the compensation point $(\chi)$ and can, to a first approximation, be predicted according to

$\chi=\frac{K_{\mathrm{a}} \cdot\left[\mathrm{NH}_{4(\mathrm{aq})}^{+}\right]}{K_{\mathrm{H}} \cdot\left[\mathrm{H}^{+}\right]}$,

where $\left[\mathrm{H}^{+}\right]$is the concentration of the hydronium ion in solution. If the atmospheric mixing ratio of $\mathrm{NH}_{3}$ over a surface 
is below this value, net emission from the surface pool will be expected until the equilibrium $\mathrm{NH}_{3}$ value (i.e. $\chi$ ) is reached and vice versa. In order to account for the temperature dependence of the equilibrium constants, the van 't Hoff equation must be applied so Eq. (1) can be updated to

$\chi=13587 \cdot \Gamma \cdot e^{\frac{-10396 K}{T}} \times 10^{9}$,

where $T$ is the temperature of the surface reservoir in $K, \Gamma$ is the emission potential equal to the ratio between $\left[\mathrm{NH}_{4}^{+}\right]$ and $\left[\mathrm{H}^{+}\right]$in the surface reservoir $\left(\Gamma=\left[\mathrm{NH}_{4}^{+}\right] /\left[\mathrm{H}^{+}\right]\right)$, and $\chi$ is given in ppb or $\mathrm{nmol} \mathrm{mol}^{-1}$ (Nemitz et al., 2001, 2004). A large $\Gamma$ indicates the surface has a high propensity to emit $\mathrm{NH}_{3}$ since it is directly proportional to $\chi$. Values for $K_{\mathrm{H}}\left(10^{-1.76} \mathrm{~atm} \mathrm{M}^{-1}\right)$ and enthalpy of vaporization $\left(34.18 \mathrm{~kJ} \mathrm{~mol}^{-1}\right)$ at $25^{\circ} \mathrm{C}$ were obtained from Dasgupta and Dong (1986). The $\mathrm{K}_{a}$ and enthalpy of dissociation of $\mathrm{NH}_{4}^{+}$at $25^{\circ} \mathrm{C}$ are $10^{-9.25} \mathrm{M}$ and $52.21 \mathrm{~kJ} \mathrm{~mol}^{-1}$, respectively (Bates and Pinching, 1950).

This conceptual model of a compensation point for $\mathrm{NH}_{3}$ was first suggested by Farquhar et al. (1980). Over the subsequent decades, numerous laboratory and field studies over a wide range of land types have been undertaken to validate and improve this framework. Single-layer exchange models were developed in the 1990s to account for bi-directional exchange with plant stomata and deposition to the cuticle (e.g. Sutton et al., 1993, 1995, 1998). A two-layer model was developed by Nemitz et al. (2001) that also included exchange with the soil. Nemitz et al. (2000) were able to create a multi-layer model that allowed for exchange with different layers within the canopy (i.e. inflorescences, bottom leaves) of oilseed rape. The flux of $\mathrm{NH}_{3}\left(F_{\mathrm{NH}_{3}}\right)$ above a surface reservoir can be calculated from $\chi$ with an exchange velocity $\left(v_{\mathrm{ex}}\right)$ using the following:

$F_{\mathrm{NH}_{3}}=v_{\mathrm{ex}} \cdot\left(\chi-\left[\mathrm{NH}_{3(\mathrm{~g})}\right]\right)$

The $v_{\mathrm{ex}}$ (units of $\mathrm{m} \mathrm{s}^{-1}$ ) can be parameterized by applying resistances in either a series and/or parallel schematic. These resistances represent physical barriers to mass transfer and are analogous to electrical resistances. The number of resistances applied is dependent on how many surface reservoirs are incorporated into the field-scale model. In all cases, aerodynamic $\left(R_{\mathrm{a}}\right)$ and quasi-laminar $\left(R_{\mathrm{b}}\right)$ resistances must be considered to account for the turbulence between the surface reservoir and $\mathrm{NH}_{3(\mathrm{~g})}$ measurement height.

Numerous pathways are present for bi-directional exchange over land: via plant stomata, soil pore water, and ground litter. For each compartment there exists a $\chi$ which is dependent on the surface properties given in Eqs. (1) and (2). Significant effort has gone into measuring and modelling $\mathrm{NH}_{3}$ fluxes over a wide variety of land types to provide a more thorough understanding of this framework (Massad et al., 2010; Zhang et al., 2010, and references therein). Canopy-scale resistance models of varying complexity have been developed and successfully employed to mechanistically describe $\mathrm{NH}_{3}$ fluxes (e.g. Nemitz et al., 2001; Personne et al., 2009; Sutton et al., 1995). A detailed list of these models is available in Flechard et al. (2013).

While extremely useful, these mechanistic canopy-scale models are often too complex to be directly incorporated into regional or global chemical transport models. As a result, recent efforts have focused on simplifying previous models by empirically parameterizing certain components (usually $\Gamma$ ) with either a constant for each land type or a function using parameters (i.e. fertilizer application, regional long-term $\mathrm{NH}_{3}$ concentration) that are easily assimilated into the regional and global models (Bash et al., 2013; Cooter et al., 2010, 2012; Pleim et al., 2013; Wen et al., 2013; Wichink Kruit et al., 2010, 2012). Incorporating bidirectional $\mathrm{NH}_{3}$ exchange in these large-scale atmospheric models generally improves model performance. For instance, Bash et al. (2013) reduced the biases and error in both $\mathrm{NH}_{\mathrm{x}}$ deposition and aerosol concentration by coupling CMAQ (Community Multiscale Air-Quality) to an agro-ecosystem model and allowing for bi-directional exchange over the continental United States. Wichink Kruit et al. (2012) incorporated bi-directional exchange in the chemical transport model LOTOS-EUROS and found better agreement between measured and modelled $\mathrm{NH}_{3}$ mixing ratios across Europe, although some domains were still biased low by up to a factor of 2. Large uncertainties still exist for the parameterizations of $\Gamma$ for both stomata and soil over most land types as a result of sparse measurements. Field measurements of soil and vegetation $\left[\mathrm{NH}_{4}^{+}\right]$and $\left[\mathrm{H}^{+}\right]$, along with atmospheric $\mathrm{NH}_{3}$ mixing ratios, are required to evaluate the performance of regional air quality models attempting to parameterize bidirectional exchange.

Reviews by Massad et al. (2010) and Zhang et al. (2010) have summarized the studies to date that have explored bidirectional surface-atmosphere $\mathrm{NH}_{3}$ fluxes over a wide variety of different land types. The majority have focused on biosphere-atmosphere (i.e. stomatal) or canopy-atmosphere (i.e. sum of stomatal, litter, and soil) exchange. In the former, both stomatal and cuticular resistances are incorporated (Massad et al., 2010 and references therein). Indeed, there have been a limited number of studies strictly examining soil-atmosphere bi-directional exchange. One reason is that if a significant canopy (i.e. forest or crops) is present, a significant fraction of soil $\mathrm{NH}_{3}$ emissions are expected to be recaptured by the canopy before leaving it (Nemitz et al., 2000). For instance, Walker et al. (2013) estimated that $\sim 76 \%$ of soil $\mathrm{NH}_{3}$ emissions are recaptured by the canopy in a fertilized corn field during peak leaf area index (LAI).

Agricultural fields and fertilized croplands have traditionally been the focus of $\mathrm{NH}_{3}$ bi-directional exchange studies due to their high propensity to emit $\mathrm{NH}_{3}$ (Massad et al., 2010; Zhang et al., 2010 and references therein). Semi-natural and non-fertilized ecosystems have been examined less often. Although these areas are much less likely to be large sources 


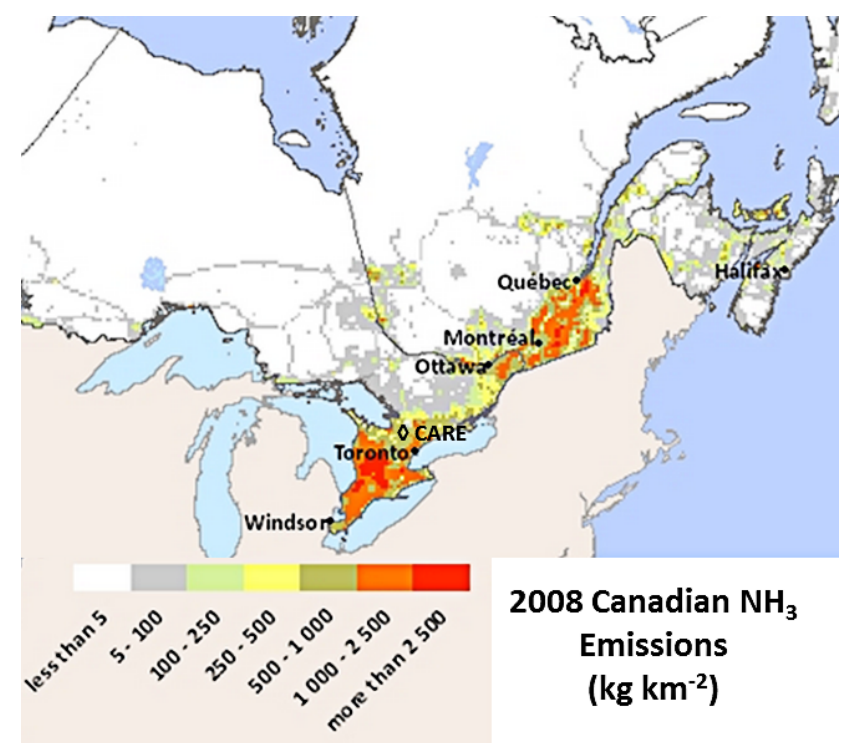

Figure 1. Location of CARE $(\diamond)$ and major cities in the surrounding area. The map is coloured by annual $\mathrm{NH}_{3}$ emissions according to the 2008 emission inventory.

of $\mathrm{NH}_{3}$, they account for a large land fraction and have the potential to impact the quality of atmospheric ammonia predictions from these updated regional-scale models. In particular, there have been fewer studies measuring $\mathrm{NH}_{3}$ fluxes over grasslands (e.g. Mosquera et al., 2001; Spindler et al., 2001). Several studies (David et al., 2009; Herrmann et al., 2009; Milford et al., 2001; Sutton et al., 2001, 2009) have explored how different grassland management practices (cutting and fertilization) affect $\mathrm{NH}_{3}$ fluxes; however, all of these studies were performed in fields that had received some degree of fertilization within the last 10 years. To our knowledge, only Wichink Kruit et al. (2007) have investigated $\mathrm{NH}_{3}$ bi-directional exchange over a non-fertilized grassland. The authors used several denuders and the aerodynamic gradient method to measure fluxes above the canopy and then infer both a canopy $\chi$ and $\Gamma$.

Motivated by a lack of measurements in non-fertilized grasslands, this present study aims to measure $\chi$ and $\Gamma$ to provide a better constraint on these values since they are directly employed in current air quality models that represent bi-directional exchange. Atmospheric measurements are then used to estimate a soil-atmosphere flux based on a simple resistance model that has been utilized in the past (e.g. Nemitz et al., 2001). Furthermore, we present evidence that bidirectional exchange over a non-fertilized grassland can significantly impact near-surface $\mathrm{NH}_{3}$ concentrations, and that evaporation of dew can release large quantities of $\mathrm{NH}_{3}$.

\section{Methods and materials}

\subsection{Field site}

Measurements were taken from 12 August to 2 October 2012 at a rural site near Egbert, ON, located approximately $70 \mathrm{~km}$ north of Toronto. The long-term sampling site, Centre for Atmospheric Research Experiments (CARE, $44^{\circ} 13^{\prime} 51^{\prime \prime} \mathrm{N}, 79^{\circ} 46^{\prime} 58^{\prime \prime} \mathrm{W}, 251 \mathrm{~m}$ a.s.1.), is operated by Environment Canada and situated in an agricultural area. Figure 1 shows the location of CARE in relation to major Canadian cities and is coloured according to annual $\mathrm{NH}_{3}$ emissions from 2008 (NPRI, 2008). Canada's National Pollutant Release Inventory (NPRI) does not include soil or vegetative emissions from non-managed ecosystems. The site is located on a sharp transition with high $\mathrm{NH}_{3}$ emissions to the south and negligible emissions to the north. Air masses originating from the south are typically polluted since they pass over urban, industrial, and agricultural areas of southern Ontario and the north-eastern United States, whereas cleaner air usually arrives from the north (e.g. Rupakheti et al., 2005). As a result, soil-atmosphere exchange of $\mathrm{NH}_{3}$ can be examined under a wide range of atmospheric pollution regimes.

The site itself is surrounded by 60 ha of semi-natural, nonfertilized grassland with no overlying canopy. The month of August was relatively dry with cumulative precipitation totalling $8 \mathrm{~mm}$, whereas September had $75 \mathrm{~mm}$ of precipitation. The soil sampling area is contained within a radius of $10 \mathrm{~m}$ as this is the approximate flux footprint of the air sampling instrumentation explained in Sect. 2.4. Fertilizer has not been applied to the soil in at least 15 years. Grass at the site was cut on 27 June but remained uncut for the duration of the study. Over the course of the study, the grass grew from about $10 \mathrm{~cm}$ to a final height of $20 \mathrm{~cm}$. The soil is sandy loam with an organic carbon content of roughly $5 \%$ and a cation exchange capacity (CEC) of $22.7 \mathrm{cmol} \mathrm{kg}^{-1}$. The CEC reflects the soil's ability to retain cations (including $\mathrm{NH}_{4}^{+}$) and at this site is an intermediate value relative to other soils.

\subsection{Bi-directional exchange framework}

For surfaces with minimal vegetation and a high soil emission potential $\left(\Gamma_{\text {soil }}\right)$, the exchange between the soil and atmosphere is expected to dominate the bi-directional flux (Personne et al., 2009; Sutton et al., 2009). In these environments, it should be reasonable to estimate $v_{\mathrm{ex}}$ by only considering resistances affecting the exchange across the soilatmosphere interface. As such, $v_{\mathrm{ex}}$ in this paper is approximated using Eq. (4), which was derived from Su et al. (2011), who parameterized HONO soil fluxes in a similar fashion. This method is also the same as the two-layer resistance model developed by Nemitz et al. (2001) but ignores the stomatal and cuticular components.

$v_{\mathrm{ex}}=\frac{1}{R_{\mathrm{a}}+R_{\mathrm{b}}+R_{\mathrm{inc}}+R_{\mathrm{soil}}}$ 
The aerodynamic $\left(R_{\mathrm{a}}\right)$ and quasi-laminar $\left(R_{\mathrm{b}}\right)$ resistances reflect the macro- and molecular-scale turbulence, respectively, between the soil and measurement height of $\mathrm{NH}_{3(\mathrm{~g})}$. The incanopy $\left(R_{\text {inc }}\right)$ and soil $\left(R_{\text {soil }}\right)$ resistances account for processes within the canopy and at the soil interface that hinder the exchange of gases. According to the theory outlined in Hicks et al. (1987), $R_{\mathrm{a}}$ and $R_{\mathrm{b}}$ can be calculated as such:

$$
\begin{aligned}
& R_{\mathrm{a}}=\frac{\ln \left(z_{\mathrm{ref}}\right)-\ln \left(z_{0}\right)}{\kappa \cdot u_{*}}, \\
& R_{\mathrm{b}}=\frac{2}{\kappa \cdot u_{*}} \cdot\left(\frac{S c}{P r}\right)^{2 / 3},
\end{aligned}
$$

where $z_{\text {ref }}$ is the height of the $\mathrm{NH}_{3}$ measurement $(2.7 \mathrm{~m})$, $z_{0}$ the roughness length, equal to $0.05 \mathrm{~m}$ for uncut grass (Seinfeld and Pandis, 2006), and the von Karman constant $\kappa=0.4$. The Schmidt number $(S c=0.58)$ and Prandtl number $(P r=0.72)$ are taken from Hicks et al. (1987) and account for the diffusivity of $\mathrm{NH}_{3}$ and heat transfer, respectively. The friction velocity, $u_{*}$, can be calculated by

$u_{*}=\sqrt[4]{{\overline{u^{\prime} w^{\prime}}}^{2}+{\overline{v^{\prime} w^{\prime}}}^{2}}$

where $u^{\prime}$ and $v^{\prime}$ are the deviations from the streamline corrected half-hour mean of the horizontal component of wind velocity and $w^{\prime}$ is the vertical component (Wilczak et al., 2001).

Parameterizations for $R_{\text {inc }}$ and $R_{\text {soil }}$ vary and are empirically determined through measurements of net vertical flux above a given bulk surface. The former is found to be dependent on the canopy height, season, and land use, whereas the latter is primarily dictated by the Henry's law constant and reactivity of the pollutant. For the present study, values of $R_{\text {inc }}=100 \mathrm{~s} \mathrm{~m}^{-1}$ and $R_{\text {soil }}=60 \mathrm{~s} \mathrm{~m}^{-1}$ are employed based on the work by Wesely (1989). These values correspond to resistances for a range land in midsummer with lush vegetation and a soil $\mathrm{pH}$ of 6 .

It should be reiterated that using Eqs. (3) to (7) to estimate soil-atmosphere $\mathrm{NH}_{3}$ fluxes neglects any vegetative effects (e.g. recapture of $\mathrm{NH}_{3}$, stomatal emission) and that this serves only as an approximation of $\mathrm{NH}_{3}$ fluxes between the soil and the atmosphere.

\subsection{Soil measurements}

Measurements of soil $\left[\mathrm{NH}_{4}^{+}\right], \mathrm{pH}$, and temperature were necessary for calculating the $\chi$. Soil cores were collected in triplicate on 6 days during the campaign, all within 30 feet of the atmospheric measurement inlet. The sampling methodology outlined below is based on work done by $\mathrm{Li}$ et al. (2012) and van Miegroet (1995). Samples were collected six times throughout the campaign on the days listed in Table 1. Sites 1,2 , and 3 correspond to small $\left(\sim 1 \mathrm{~m}^{2}\right)$ areas $10 \mathrm{~m}$ west, directly below, and $10 \mathrm{~m}$ east of the sonic anemometer, respectively. The soil was sampled more frequently towards the end of the campaign since meteorology (i.e. precipitation, air temperature) was more variable and was expected to perturb the $\Gamma_{\text {soil }}$ to a greater extent than in August when meteorological conditions were more consistent. Specifically, the ranges in air and soil temperature were larger in September than in August. After removing grass and any residual litter (of which there was very little), a PVC tube $(5.1 \mathrm{~cm}$ inner diameter) was inserted into the ground to a depth of $10 \mathrm{~cm}$ and a soil core was removed by pulling out the tube with a soil core intact. Each core was thoroughly mixed and an $\sim 8 \mathrm{~g}$ subsample was immediately placed into a pre-weighed extract solution $(50 \mathrm{~mL}$ of $0.25 \% \mathrm{KCl} \mathrm{w} / \mathrm{w})$ and transported on ice back to the lab for analysis. After shaking for $30 \mathrm{~min}$, extracts were gravity filtered (ashless filter \#40, Whatman Ltd., Maidstone, UK) then sent through a $0.2 \mu \mathrm{m}$ PES membrane syringe filter (Pall Ion Chromatography Acrodisc ${ }^{\circledR}$, VWR International, Mississauga, ON). Ammonium, nitrate, and nitrite were then quantified using two ion chromatograph (IC) ICS-2000 systems (Dionex Inc., Sunnyvale, CA) operated with suppressed conductivity detection and reagent-free eluent (potassium hydroxide for anions, methanesulfonic acid for cations). Gradient elution schemes were optimized so that analyte peaks were baseline resolved. CS12A analytical and CG12A guard columns were used for the cation IC, and AS19 analytical and AG19 guard columns for the anion IC. In both cases, $25 \mu \mathrm{L}$ loops were used. ICs were calibrated by injection of commercially available (Dionex Corp., Sunnyvale, $\mathrm{CA})$ mixed standards of seven anions $\left(\mathrm{F}^{-}, \mathrm{Cl}^{-}\right.$, $\left.\mathrm{NO}_{2}^{-}, \mathrm{Br}^{-}, \mathrm{NO}_{3}^{-}, \mathrm{SO}_{4}^{2-}, \mathrm{PO}_{4}^{3-}\right)$ and six cations $\left(\mathrm{Li}^{+}, \mathrm{Na}^{+}\right.$, $\left.\mathrm{NH}_{4}^{+}, \mathrm{K}^{+}, \mathrm{Mg}^{2+}, \mathrm{Ca}^{2+}\right)$. Serial dilutions of the standards in matrix-matched $0.25 \% \mathrm{KCl}$ allowed for a five-point calibration which yielded reasonable calibration curves (slope of $R^{2}>0.99$ ) for all analytes. Extraction with a $0.25 \% \mathrm{KCl}$ solution proved sufficient to desorb all accessible ions in the soil matrix, yet dilute enough to allow for quantification of $\mathrm{NH}_{4}^{+}$and $\mathrm{NO}_{3}^{-}$in every sample. The inherent assumption is that the extract solution sufficiently mimics the ability of soil pore water to liberate $\mathrm{NH}_{4}^{+}$ions from the soil matrix to participate in soil-air exchange. An additional extraction into deionized water (DIW) was performed on one set of soil samples. The $\left[\mathrm{NH}_{4}^{+}\right]$measured in the DIW extract was between $30-45 \%$ of that measured with the $\mathrm{KCl}$ extraction. Extraction into DIW is an absolute lower bound on soil $\left[\mathrm{NH}_{4}^{+}\right]$since higher ionic strength solutions will desorb more $\mathrm{NH}_{4}^{+}$, and soil pore water has a much higher ionic strength than DIW. Flechard et al. (2013) and Cooter et al. (2010) have suggested fundamental analytical research is required to assess the validity of this assumption, but this is outside the scope of this current study. A field blank was run with every triplicate to account for any contamination (always less than $1 \%$ of the measured soil $\left[\mathrm{NH}_{4}^{+}\right]$) from sample handling and extraction.

Soil $\mathrm{pH}$ was measured by mixing $\sim 10 \mathrm{~g}$ of soil with an equal mass of deionized water (1:1 soil:DIW slurry). A standard pH electrode (SympHony 14002-782, VWR 
Table 1. Soil parameters measured in this study.

\begin{tabular}{|c|c|c|c|c|}
\hline Date & Site & $\begin{array}{c}{\left[\mathrm{NH}_{4}^{+}\right]} \\
\left(\mathrm{mg} \mathrm{kg}^{-1} \text { wet soil) }\right.\end{array}$ & $\begin{array}{c}\text { pH }(1: 1 \text { slurry soil : } \\
\text { deionized water })\end{array}$ & $\begin{array}{l}\text { Average } \Gamma_{\text {soil }} \\
\quad( \pm 1 \sigma)\end{array}$ \\
\hline \multirow[t]{3}{*}{13 August } & 1 & 1.4 & 6.9 & $978 \pm 750$ \\
\hline & 2 & 1.67 & 7.3 & \\
\hline & 3 & 0.85 & 7 & \\
\hline \multirow[t]{3}{*}{28 August } & 1 & 1.43 & 6.6 & $290 \pm 110$ \\
\hline & 2 & 0.31 & 7 & \\
\hline & 3 & 0.87 & 6.9 & \\
\hline \multirow[t]{3}{*}{13 September } & 1 & 1.31 & 5.81 & $51 \pm 20$ \\
\hline & 2 & 0.17 & 6.87 & \\
\hline & 3 & 0.51 & 6.09 & \\
\hline \multirow[t]{3}{*}{20 September } & 1 & 1.01 & 5.8 & $176 \pm 140$ \\
\hline & 2 & 0.89 & 6.81 & \\
\hline & 3 & 0.94 & 6.53 & \\
\hline \multirow[t]{3}{*}{25 September } & 1 & 2.1 & 6.22 & $172 \pm 43$ \\
\hline & 2 & 0.6 & 6.57 & \\
\hline & 3 & 0.93 & 6.59 & \\
\hline \multirow[t]{3}{*}{27 September } & 1 & 0.61 & 6.16 & $91 \pm 40$ \\
\hline & 2 & 0.46 & 6.59 & \\
\hline & 3 & 0.25 & 6.95 & \\
\hline
\end{tabular}

International, Mississauga, ON) was immediately immersed in the slurry until a stable $\mathrm{pH}$ reading was obtained. This was done in triplicate for each soil core, and an average $\mathrm{pH}$ for each was calculated. Performing the $\mathrm{pH}$ measurements in a saline solution of $0.25 \% \mathrm{KCl}$ desorbs more $\mathrm{H}^{+}$and was found to lower the $\mathrm{pH}$ reading by up to 1 unit relative to extraction into deionized water, which has been reported previously (e.g. Walker et al., 2014). Soil temperature was logged hourly using five in situ sensors (iButtons, Maxim Integrated, San Jose, CA) placed $10 \mathrm{~cm}$ deep dispersed across the $30 \mathrm{foot}$ radius of the soil sampling area. Moisture content was determined gravimetrically for a subsample $(\sim 3 \mathrm{~g})$ of each core by drying in an oven at $105^{\circ} \mathrm{C}$ for at least $24 \mathrm{~h}$.

\subsection{Atmospheric measurements}

Ambient $\mathrm{NH}_{3(\mathrm{~g})}$ mixing ratios were needed to infer both the direction and magnitude of soil-atmosphere fluxes. Measurements of $\mathrm{NH}_{4}^{+}, \mathrm{SO}_{4}^{2-}, \mathrm{NO}_{3}^{-}$in $\mathrm{PM}_{2.5}$ and their precursor gases $\left(\mathrm{SO}_{2}\right.$, and $\left.\mathrm{HNO}_{3}\right)$ were also important to aid in interpretation of air mass trajectory. These water-soluble gases and ions in $\mathrm{PM}_{2.5}$ were measured continuously online every hour with the Ambient Ion Monitor Ion Chromatographs (AIM-IC) system (Model 9000D, URG, Chapel Hill, NC). The set-up has been explained in detail elsewhere (Markovic et al., 2012) and is described here only briefly. Ambient air is pulled at $3 \mathrm{~L} \mathrm{~min}^{-1}$ through a $\mathrm{PM}_{2.5}$ impactor to remove coarse particles. Gases are stripped from the sample flow by a liquid parallel plate denuder with a $2 \mathrm{~mm} \mathrm{H}_{2} \mathrm{O}_{2}$ solution continuously flowing over the surface. Particles have sufficient inertia to pass through the denuder assembly and enter a supersaturated steam condensation coil where they are grown hygroscopically and collected as an aqueous solution. The aqueous sample then travels through a $22 \mathrm{~m}$ sample line to the IC systems where the $\sim 5 \mathrm{~mL}$ aliquots (collected over an hour) are separately injected and quantified for water soluble ions. The inlet box was mounted on a tower $3 \mathrm{~m}$ above the ground.

The AIM-IC was deployed using CS17 and AS19 analytical columns, CG17 and AG19 guard columns, and TCCULP1 and TAC-ULP1 concentrator columns. Suppressed conductivity detection and reagent-free gradient elution were used. Five-point calibrations were performed at the beginning, middle, and end of the campaign. Standard solutions of known concentration were made by serial dilution of commercially available standards of mixed anions and cations discussed in the previous section.

Backgrounds were acquired by overflowing the inlet with high-purity zero air for $24 \mathrm{~h}$ and averaging the peak area signal acquired. This average peak area was subtracted from the peak areas obtained while sampling ambient air. Detection limits were determined by taking 3 times the standard deviation of the peak area during the final $20 \mathrm{~h}$ of the zero air experiment and converting it to either a mixing ratio or mass loading using the calibration curves and assuming a flow of $3 \mathrm{~L} \mathrm{~min}^{-1}$, pressure of $760 \mathrm{~mm} \mathrm{Hg}$ and temperature of $298 \mathrm{~K}$.

Atmospheric species of primary interest for this study are $\mathrm{NH}_{4}^{+}, \mathrm{SO}_{4}^{2-}, \mathrm{NO}_{3}^{-}$in $\mathrm{PM}_{2.5}$ and their precursor gases $\left(\mathrm{NH}_{3}\right.$, 


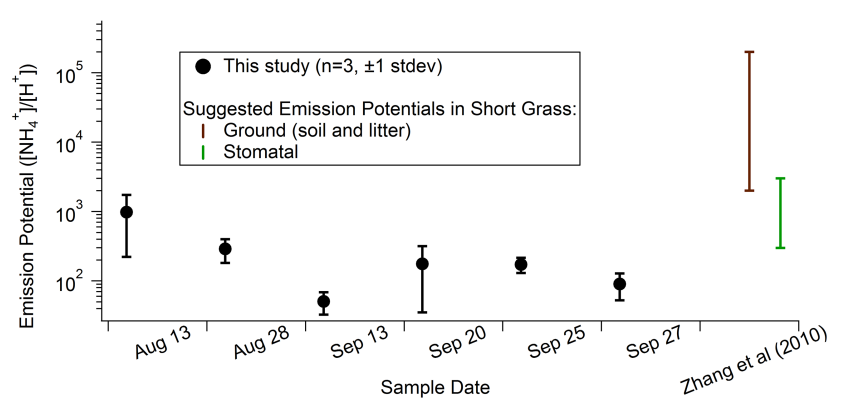

Figure 2. Soil emission potentials $\left(\Gamma_{\text {soil }}\right)$ measured throughout this study. Black circles represent the average of three measurements $\pm 1 \sigma$. A review by Zhang et al. (2010) suggests $\Gamma$ ranges for ground $\left(\Gamma_{\mathrm{g}}\right)$ and stomata $\left(\Gamma_{\text {stom }}\right)$ for low and high nitrogen input grasslands. These ranges are shown in brown $\left(\Gamma_{\mathrm{g}}\right)$ and green $\left(\Gamma_{\text {stom }}\right)$.

$\mathrm{SO}_{2}$, and $\mathrm{HNO}_{3}$ ), for which the limits of detection were 0.2 , 0.003 , and $0.008 \mathrm{ppb}$ for $\mathrm{NH}_{3}, \mathrm{SO}_{2}$, and $\mathrm{HNO}_{3}$, respectively. For $\mathrm{NH}_{4}^{+}, \mathrm{SO}_{4}^{2-}$, and $\mathrm{NO}_{3}^{-}$in the particle phase the detection limits were $0.025,0.04$, and $0.04 \mu \mathrm{g} \mathrm{m}^{-3}$, respectively.

Friction velocity $\left(u_{*}\right)$ parameters were calculated from wind velocity measured with a 3-D sonic anemometer (model CSAT3, Campbell Scientific, Logan, UT) operating at $10 \mathrm{~Hz}$. Hourly relative humidity $(\mathrm{RH})$ and air temperature (in ${ }^{\circ} \mathrm{C}$ ) at CARE were measured by an Environment Canada weather station located $20 \mathrm{~m}$ north of the sonic anemometer. This data was obtained from the Environment Canada website (http://climate.weather.gc.ca/data_index_e.html).

The Hybrid Single-Particle Lagrangian Integrated Trajectory (HYSPLIT) model was used to compute $48 \mathrm{~h}$ backtrajectories throughout the campaign in order to assess air parcel history (Draxler and Rolph, 2013). The model was run four times per day with parcels arriving at a height of $100 \mathrm{~m}$ above CARE at 02:00, 08:00, 14:00, and 20:00 LT. Resolution of the meteorology model (EDAS) was set to 40 by $40 \mathrm{~km}$.

\section{Results and discussion}

\subsection{Soil emission potential measurements}

Figure 2 shows the measured $\Gamma_{\text {soil }}$ for the six soil sampling dates in this study. Soil $\left[\mathrm{NH}_{4}^{+}\right]$and $\mathrm{pH}$ measurements used to determine the $\Gamma_{\text {soil }}$ are shown in Table 1. The variation in $\Gamma_{\text {soil }}$ was up to an order of magnitude on some days (13 August and 20 September) yet was more consistent on others (i.e. 13 and 25 September). Both August dates have the highest $\Gamma_{\text {soil }}$ suggesting there might be some seasonal variability, as has been observed for stomatal emission potentials $\left(\Gamma_{\text {stom }}\right)$ (Loubet et al., 2002). However, a similar trend cannot be confirmed for this study due to the relatively short time frame and the inherent heterogeneity of soil. Also shown in Fig. 2 is the range of ground emission potentials $\left(\Gamma_{\mathrm{g}}\right)$ in grasslands suggested by Zhang et al. (2010). $\Gamma_{\mathrm{g}}$ includes both soil and litter, but during this study there was a negligible amount of litter on the ground; therefore, $\Gamma_{\mathrm{g}}$ and $\Gamma_{\text {soil }}$ should be analogous. The suggested range in $\Gamma_{\mathrm{g}}(2000$ to 200000$)$ is based on 14 values from six studies, all of which were in fertilized grasslands. Of these studies, only two (David et al., 2009; Mattsson et al., 2009) directly measured $\Gamma_{\mathrm{g}}$, whereas the other four either inferred it from measurements of dead or dying leaves (Herrmann et al., 2009; Mattsson and Schjoerring, 2003) or modelled it (Burkhardt et al., 2009; Personne

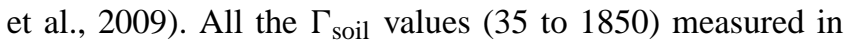
this study are below the range from the Zhang et al. (2010) review, likely because the field at CARE is non-fertilized and so has a lower $N$ content. Suggested ranges of $\Gamma_{g}$ from Zhang et al. (2010) for various land types were recently incorporated into a regional air quality model (STILT-Chem) by Wen et al. (2013) to allow for bi-directional exchange. The authors found the updated model, using $\Gamma_{\mathrm{g}}=2000$ over grasslands, overestimates $\mathrm{NH}_{3(\mathrm{~g})}$ in sites with lower $\mathrm{NH}_{3(\mathrm{~g})}$ concentrations (i.e. CARE). This could be a consequence of overestimating $\Gamma_{\mathrm{g}}$ in these regions, as implied by the $\Gamma_{\text {soil }}$ measurements given here.

Massad et al. (2010) carried out a similar review and suggested that $\Gamma_{\mathrm{g}}$ be parameterized as 500 in non-fertilized, semi-natural environments without vegetation. To our knowledge, the results presented here represent the first values of $\Gamma_{\text {soil }}$ directly measured in a non-fertilized grassland. These measurements underscore the importance of distinguishing between fields that receive fertilization and those that do not. The $\Gamma_{\mathrm{g}}$ range from Zhang et al. (2010) is not applicable to the field at CARE, whereas the estimation $\left(\Gamma_{\mathrm{g}}=500\right)$ from Massad et al. (2010) is more suitable.

It is worth comparing $\Gamma_{\text {soil }}$ to the range of stomatal emission potentials $\left(\Gamma_{\text {stom }}\right)$ in grasslands proposed by Zhang et al. (2010) (Fig. 2, green line). $\Gamma_{\text {stom values (300 to } 3000)}$ are based on roughly 50 measurements from over two dozen studies which reflect the narrower range in $\Gamma_{\text {stom }}$ compared to $\Gamma_{\mathrm{g}}$. Massad et al. (2010) also parameterized $\Gamma_{\text {stom }}$, but did so by empirically fitting measurements to total annual $\mathrm{N}$ input instead of using a constant value for each land use type.

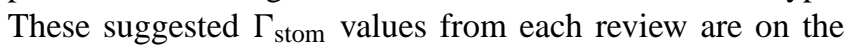
same order as the $\Gamma_{\text {soil }}$ measured in this study, suggesting that in a non-fertilized field, the soil and vegetation might have a very similar propensity to either emit or uptake $\mathrm{NH}_{3}$ (i.e. they likely have similar $\chi$ ).

\subsection{Inferred soil compensation point and fluxes}

A linear interpolation of $\Gamma_{\text {soil }}$ between the six sampling dates in combination with hourly soil temperature measurements were used to generate a time series of soil compensation point $\chi_{\text {soil }}$ (black trace in Fig. 3a) according to Eq. (2). The shaded region around $\chi_{\text {soil }}$ was calculated from a linear interpolation of $\pm 1 \sigma$ in $\Gamma_{\text {soil }}$ measurements and therefore reflects the uncertainty in $\chi_{\text {soil }}$ attributed to variability in soil $\mathrm{pH}$ and 

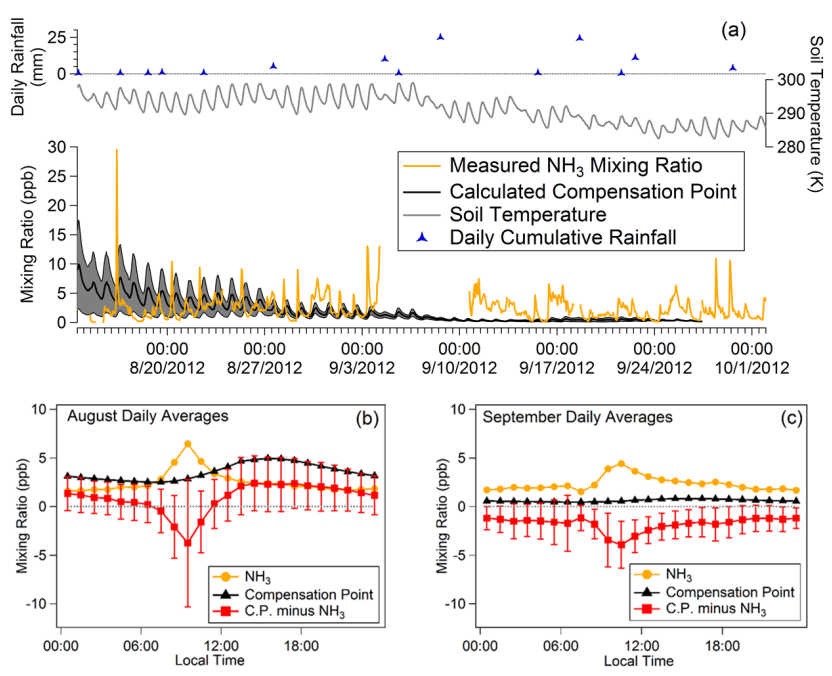

Figure 3. Time series of $\mathrm{NH}_{3}$ mixing ratio $\left(\left[\mathrm{NH}_{3}\right]\right.$, orange trace), $\chi_{\text {soil }}$ (black trace), daily cumulative rainfall (blue markers) and soil temperature $\left(T_{\text {soil }}\right.$, grey trace) throughout the campaign (a). $\chi_{\text {soil }}$ was calculated using a linear interpolation of $\Gamma_{\text {soil }}$ and hourly soil temperature measurements. The shaded region around $\chi_{\text {soil }}$ was calculated by linear interpolation of $\pm 1 \sigma$ of $\Gamma_{\text {soil }}$ and reflects the uncertainty in $\chi_{\text {soil }}$ as a result of uncertainty in $\Gamma_{\text {soil }}$ measurements. Panels (b) and (c) show time of day plots for the average $\left[\mathrm{NH}_{3}\right]$, $\chi_{\text {soil }}$, and difference between the two $\left(\chi_{\text {soil }}-\left[\mathrm{NH}_{3}\right]\right.$, red trace $)$ for August and September, respectively. Errors bars in (b) and (c) represent $\pm 1 \sigma$ and are only included for the difference trace for clarity.

$\left[\mathrm{NH}_{4}^{+}\right]$. Hourly gas-phase $\mathrm{NH}_{3}$ measured by the AIM-IC (orange trace) is also shown. These two traces frequently cross meaning that repeated switching between soil emission and atmospheric deposition is predicted. There is a clear decline in $\chi_{\text {soil }}$ throughout the campaign that is mostly attributable to a decrease in soil temperature $\left(T_{\text {soil }}\right)$ as shown by the grey trace at the top of Fig. 3a. Precipitation can also be important factor for $\mathrm{NH}_{3}$ fluxes - both Cooter et al. (2010) and Walker et al. (2013) observed emission "pulses" of $\mathrm{NH}_{3}$ over agricultural soils within $24 \mathrm{~h}$ after rainfall. Elevated $\left[\mathrm{NH}_{3}\right]$ levels are seen on 13 August, 28 August, and 22 September following $0.4 \mathrm{~mm}, 5.0 \mathrm{~mm}$, and $10.9 \mathrm{~mm}$ of rain. Reasons for this could include increased soil $\mathrm{NH}_{4}^{+}$available for exchange, increased diffusion of $\mathrm{NH}_{3}$ through soil, and/or increased $\mathrm{N}$ inputs to the surface as a result of wet deposition.

There is a diurnal trend in $\chi_{\text {soil }}$ with lower values during the night-time that is a consequence of $\mathrm{T}_{\text {soil }}$ and has been observed before for stomatal compensation points (Van Hove et al., 2002). It is possible there is a diurnal trend in $\Gamma_{\text {soil }}$ that is not captured by the periodic soil sampling regime. However, this is unlikely since additional measurements from a nearby site found that spatial heterogeneity in soil $\left[\mathrm{NH}_{4}^{+}\right]$was much larger than the temporal variability in 24 soil grabs taken $6 \mathrm{~h}$ apart (soil grabs were in triplicate) over the course of 2 days.

The $\chi_{\text {soil }}$ diurnal trends are more evident in Fig. $3 \mathrm{~b}$ and c, which show time-of-day plots for August and September, re-

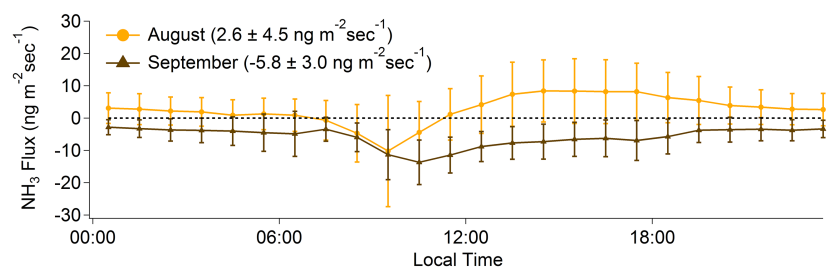

Figure 4. Time-of-day plot showing the average hourly $\mathrm{NH}_{3}$ flux in August (orange trace) and September (brown trace). A positive flux indicates emission from the soil, whereas a negative flux indicates deposition from the atmosphere.

spectively. During both months, $\mathrm{NH}_{3}$ peaks between 08:0010:00 in the morning and is typically at a minimum during the evening where it plateaus at around $2 \mathrm{ppb}$, which has been observed previously in the region (e.g. Ellis et al., 2011). Mixing ratios were fairly similar in both months, although the morning peak in August was larger than in September. On the other hand, $\chi_{\text {soil }}$ values were significantly lower in September as a result of lower soil temperatures. Accordingly, the diurnal profiles of the difference between $\chi_{\text {soil }}$ and $\left[\mathrm{NH}_{3}\right]$ (red trace) in Fig. $3 \mathrm{~b}$ and c are distinct. In August, the difference between $\chi_{\text {soil }}$ and $\left[\mathrm{NH}_{3}\right]$ is positive throughout the majority of the day (excluding 07:00-11:00 in the morning), indicating a net flux from the soil to the atmosphere. On the other hand, in September the difference is negative throughout the entire day, meaning the soil is a continuous sink for atmospheric $\mathrm{NH}_{3}$. This suggests a clear transition from the soil being a net source to a net sink for $\mathrm{NH}_{3}$ due to lower soil temperatures. It should be noted that grass senescence had not yet begun and that there was no appreciable accumulation of litter, which has been shown to act as a strong source of $\mathrm{NH}_{3}$ (e.g. David et al., 2009; Mattsson et al., 2009; Mattsson and Schjoerring, 2003).

In order to determine the magnitude of this exchange, the $v_{\mathrm{ex}}$ was estimated using Eqs. (4) to (7) and the flux was calculated from Eq. (3). The diurnal profile of $\mathrm{NH}_{3}$ fluxes (in $\mathrm{n} \mathrm{m}^{-2} \mathrm{~s}^{-1}$ ) for both months is shown in Fig. 4. Throughout August there is an average net $\mathrm{NH}_{3}$ emission from the soil of $2.6 \pm 4.5 \mathrm{ng} \mathrm{m}^{-2} \mathrm{~s}^{-1}$. In September, there was an average net deposition of $5.8 \pm 3.0 \mathrm{ng} \mathrm{m}^{-2} \mathrm{~s}^{-1}$ from the atmosphere to the surface. Average fluxes measured by Wichink Kruit et al. (2007) were $4 \mathrm{ng} \mathrm{m}^{-2} \mathrm{~s}^{-1}$ in summer and $-24 \mathrm{ng} \mathrm{m}^{-2} \mathrm{~s}^{-1}$ in autumn, which are of the same order of the flux values estimated in this study. Wichink Kruit et al. (2007) used their measured fluxes to infer a canopy emission potential ( $\left.\Gamma_{\text {canopy }}\right)$ using data points where cuticular deposition can be neglected (dry conditions) and stomatal exchange is dominant (daytime). Exchange with the soil is ignored in their study due to the low soil $\mathrm{pH}$ (about $\mathrm{pH}=5$ ); however, this would not be a valid assumption in this study as the soil $\mathrm{pH}$ at CARE is about 7, as shown in Table 1 . Nonetheless, the inferred $\Gamma_{\text {canopy }}$ was 2200 and is higher than the $\Gamma_{\text {soil }}$ measured in this study. At least to a first 

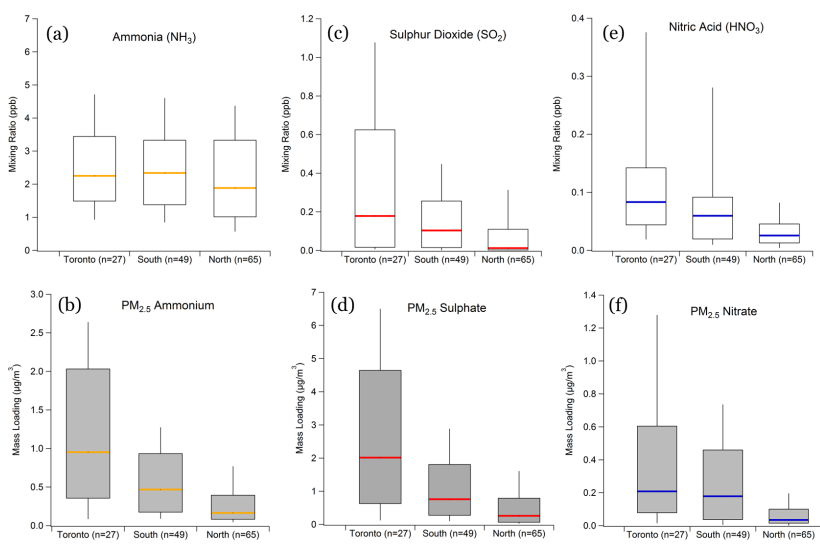

Figure 5. Atmospheric concentrations of (a) $\mathrm{NH}_{3}$, (b) particulate $\mathrm{NH}_{4}^{+}$, (c) $\mathrm{SO}_{2}$, (d) particulate $\mathrm{SO}_{4}^{2-}$, (e) $\mathrm{HNO}_{3}$, and (f) particulate $\mathrm{NO}_{3}^{-}$binned by air mass origin calculated from HYSPLIT backtrajectories every $6 \mathrm{~h}$ throughout the campaign. The line denotes the median value, the interquartile range is encompassed within the box, and the end of the whiskers are the 10th and 90th percentiles. The number of back-trajectories in each bin is given on the $x$ axis in brackets.

approximation, it appears that $\mathrm{NH}_{3}$ fluxes in both these nonfertilized fields are comparable. The larger deposition in the autumn in Wichink Kruit et al. (2007) is likely attributable to higher $\mathrm{NH}_{3}$ mixing ratios $(\sim 9 \mathrm{ppb}$ average versus $\sim 2 \mathrm{ppb}$ September average in this study). It is noteworthy that both sites are considered the same land type but likely have very different canopy-level processes driving $\mathrm{NH}_{3}$ fluxes. Specifically, the soil in Wichink Kruit et al. (2007) had a sufficiently low $\mathrm{pH}(\sim 5)$ to suppress appreciable soil-atmosphere exchange, which is not the case at CARE. Furthermore, a review by Schlesinger and Hartley (1992) estimate volatilization rates of $\mathrm{NH}_{3}$ from undisturbed grasslands are between 0.3 and $30 \mathrm{ng} \mathrm{m}^{-2} \mathrm{~s}^{-1}$, which encompasses the values from this work and that of Wichink Kruit et al. (2007).

It is also important to consider wet deposition when assessing net exchange of $\mathrm{NH}_{3}$ between the atmosphere and an ecosystem. The Canadian Air and Precipitation Monitoring Network (CAPMoN) collects daily precipitation samples at CARE and reports the results online (http://www. on.ec.gc.ca/capmon/login/login.aspx). The average $\mathrm{NH}_{4}^{+}$wet deposition rates from 2001-2011 for August and September are $12.4 \pm 4.6 \mathrm{ng} \mathrm{m}^{-2} \mathrm{~s}^{-1}$ and $11.3 \pm 5.4 \mathrm{ng} \mathrm{m}^{-2} \mathrm{~s}^{-1}$, respectively. In the context of our results (fluxes of $2.6 \pm 4.5 \mathrm{ng} \mathrm{m}^{-2} \mathrm{~s}^{-1}$ in August and $-5.8 \pm 3.0 \mathrm{ng} \mathrm{m}^{-2} \mathrm{~s}^{-1}$ in September), the site at CARE has net $\mathrm{NH}_{3}$ deposition in both months when one considers both wet deposition and bidirectional exchange. In other words, the magnitude of wet deposition fluxes is roughly 2-5 times larger than the magnitude of bi-directional exchange. However, it is important to note that wet deposition occurs in discrete events, whereas dry exchange is continuous.

\subsection{Evidence for bi-directional exchange}

Since CARE lies on a sharp gradient between high $\mathrm{NH}_{3}$ emissions to the south and low emissions to north (Fig. 1), one might expect air masses from the north to be lower in $\mathrm{NH}_{3}$ relative to air masses from the south. Similarly, the greater level of anthropogenic activity south of CARE suggests an enrichment of anthropogenic pollutants (i.e. $\mathrm{SO}_{2}, \mathrm{SO}_{4}^{2-}, \mathrm{HNO}_{3}$ and $\mathrm{NO}_{3}^{-}$) in air masses from the south. In order to interrogate this hypothesis, 2-day backtrajectories were calculated using the Hybrid Single Particle Lagrangian Integrated Trajectory (HYSPLIT) model for every $6 \mathrm{~h}$ throughout the study. Each 6-hour time stamp was then classified as having had the air mass pass through Toronto (a box defined from $43.5-44.0^{\circ} \mathrm{N}$ by $79.0-80.0^{\circ} \mathrm{N}$ ), or having originated from the north (spent more than half its time above $44.23^{\circ} \mathrm{N}$ ) or the south (spent more than half its time below $44.23^{\circ} \mathrm{N}$ and not passing through Toronto). Results from this analysis are shown in Fig. 5 and yield a distinct directional bias for all species except $\mathrm{NH}_{3}$; air masses passing through Toronto are clearly enhanced in $\mathrm{SO}_{2}, \mathrm{HNO}_{3}$, $\mathrm{NH}_{4}^{+}, \mathrm{SO}_{4}^{2-}$, and $\mathrm{NO}_{3}^{-}$but not $\mathrm{NH}_{3}$. A lack of directional bias for $\mathrm{NH}_{3}$ could be explained by proximity to a large $\mathrm{NH}_{3}$ source, but as seen in Fig. 1, there is a sharp regional (tens of kilometres) gradient in the emissions inventory suggesting that no such local source exists. A more likely explanation is that bi-directional exchange of $\mathrm{NH}_{3}$ between the surface and atmosphere modulates near-surface $\mathrm{NH}_{3}$ mixing ratios sufficiently to eliminate any directional bias that would result from traditional emission sources.

Considering the relatively low $\Gamma_{\text {soil }}$ and small magnitude of soil fluxes, it is reasonable to ask whether such an exchange could have a noticeable effect on observed $\mathrm{NH}_{3}$ mixing ratios. First, a simple calculation was performed to see if the soil reservoir contained enough $\mathrm{NH}_{4}^{+}$to sustain fluxes during the month of August. To do this, the following assumptions were made: $\mathrm{NH}_{3}$ exchange occurs in the top $10 \mathrm{~cm}$ of soil, the soil is equilibrating a $1000 \mathrm{~m}$ atmospheric boundary layer, and soil density is $1.5 \mathrm{~g} \mathrm{~cm}^{-3}$. Figure 6 shows that even during peak soil emission in the afternoon, less than $1 \%$ of the soil $\mathrm{NH}_{4}^{+}$pool is required to equilibrate the entire boundary layer. Furthermore, much of this lost soil $\mathrm{NH}_{4}^{+}$ would be regained during the inferred morning deposition event. Considering that the turnover time for most soil $\mathrm{NH}_{4}^{+}$ pools is of the order of a day (Booth et al., 2005), it is safe to assume that there is sufficient $\mathrm{NH}_{4}^{+}$in non-fertilized grasslands to maintain fluxes to the atmosphere.

Second, this exchange could only sufficiently impact $\mathrm{NH}_{3}$ mixing ratios if it occurs quickly enough. To test this, fast $\left(0.005 \mathrm{~m} \mathrm{~s}^{-1}\right.$, at $\left.14: 00\right)$ and slow $\left(0.003 \mathrm{~m} \mathrm{~s}^{-1}\right.$, at $\left.01: 00\right)$ average exchange velocities from August were used to calculate the time it would take the system (soil and atmosphere) to arrive halfway to equilibrium with an atmospheric height of $1000 \mathrm{~m}$, as well as with the height at which AIM-IC measurements were made $(3 \mathrm{~m})$. For $1000 \mathrm{~m}$, the timescale 


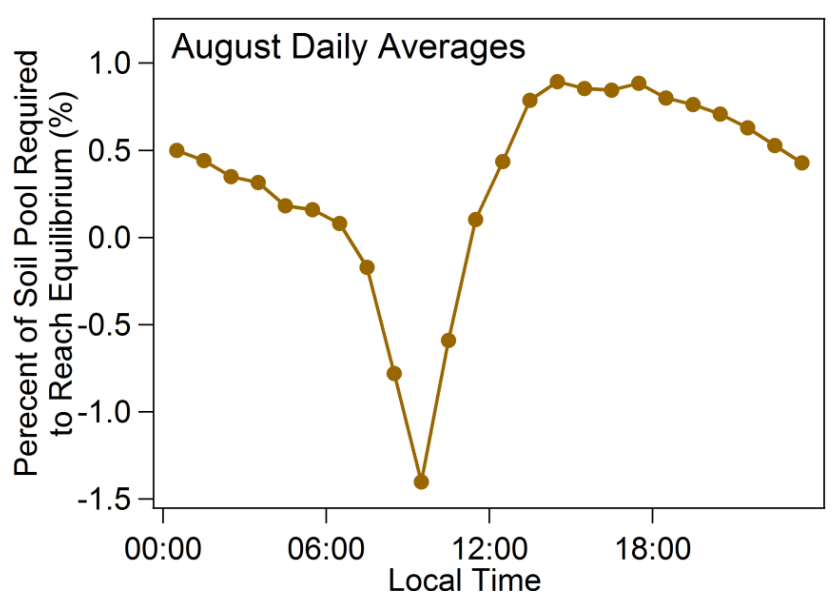

Figure 6. Estimated percent of the soil $\mathrm{NH}_{4}^{+}$pool required to equilibrate with the boundary layer (assumed to be $1000 \mathrm{~m}$ ) using the average fluxes during August. The top $10 \mathrm{~cm}$ of the soil exchanges, and the soil density is $10 \mathrm{~g} \mathrm{~cm}^{-1}$ (i.e. there are no units for "soil exchanges"). Positive values indicate fluxes are from the soil to the atmosphere (i.e. the soil is losing $\mathrm{NH}_{4}^{+}$).

is calculated to be between 40 and $62 \mathrm{~h}$ for the fast and slow $v_{\mathrm{ex}}$, respectively. However, for a height of $3 \mathrm{~m}$, only 7 and $11 \mathrm{~min}$ are required to get halfway to equilibrium. Although this calculation neglects vertical mixing beyond $3 \mathrm{~m}$ (which will occur), these short timescales suggest soilatmosphere exchange is an important component of observed negative $\left[\mathrm{NH}_{3(\mathrm{~g})}\right]$ gradients with height. In other words, soilatmosphere exchange over non-fertilized grasslands has the ability to strongly influence near-surface $\mathrm{NH}_{3}$ despite the low $\Gamma_{\text {soil }}$ (relative to fertilized fields) whereas the impact on $\mathrm{NH}_{3}$ levels throughout the boundary layer is dampened due to slower exchange.

\subsection{Morning increase of $\mathrm{NH}_{3}$}

A morning increase in $\mathrm{NH}_{3(\mathrm{~g})}$ between 08:00-10:00 is clearly evident in Fig. $3 \mathrm{~b}$ and $\mathrm{c}$ and has been observed elsewhere (e.g. Bash et al., 2010; Ellis et al., 2011; Flechard et al., 2013; Nowak et al., 2006; Wichink Kruit et al., 2007). The factors contributing to this phenomenon at CARE are not entirely clear but may include one or more of the following: dew evaporation, volatilization of particulate $\mathrm{NH}_{4} \mathrm{NO}_{3}$, emission from plants/soil, and/or mixing down of $\mathrm{NH}_{3}$ rich air entrained above the nocturnal boundary layer. Wichink Kruit et al. (2007) observed a similarly timed increase that coincided with a decrease in leaf wetness. Furthermore, Flechard et al. (1999) and Bussink et al. (1996) found that water layers sorbed on leaves can store significant quantities of $\mathrm{NH}_{3}$ even at an $\mathrm{RH}$ below $100 \%$. Although no leaf wetness sensor was employed during this study, we use nighttime RH as a surrogate for dew and fog formation. Figure 7 shows the difference between the morning $\mathrm{NH}_{\mathrm{x}}\left(\equiv \mathrm{NH}_{3(\mathrm{~g})}+\right.$ $\mathrm{NH}_{4(\text { particle })}^{+}$and the average overnight $\mathrm{NH}_{\mathrm{x}}$ concentration.

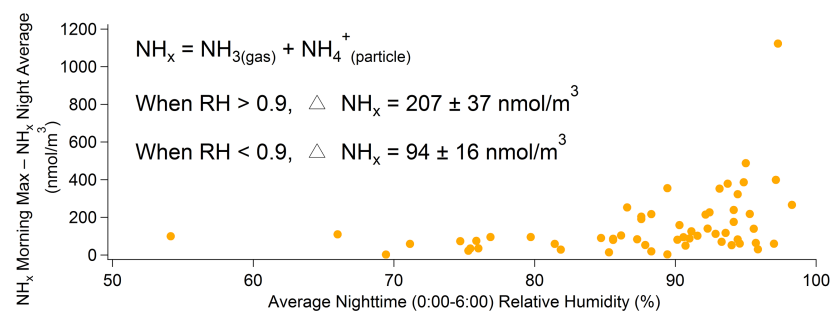

Figure 7. The magnitude of the morning $\mathrm{NH}_{\mathrm{x}}\left(\equiv \mathrm{NH}_{3(\mathrm{~g})}+\right.$ $\mathrm{NH}_{4 \text { (particle) }}^{+}$) peak subtracted from the night-time (00:00-6:00) $\mathrm{NH}_{\mathrm{x}}$ average versus the average night-time relative humidity. The latter was used as a surrogate for dew formation. The average $\Delta$ $\mathrm{NH}_{\mathrm{X}}\left( \pm 1 \sigma_{\text {mean }}\right)$ both above and below $\mathrm{RH}=0.9$ are shown inset in the figure.

$\mathrm{NH}_{\mathrm{x}}$ was chosen to eliminate any bias caused by volatilization of $\mathrm{NH}_{4} \mathrm{NO}_{3(\mathrm{p})}$ to $\mathrm{NH}_{3(\mathrm{~g})}$ and $\mathrm{HNO}_{3(\mathrm{~g})}$ as temperatures rise. Mornings following a night during which $\mathrm{RH}$ was above 0.9 had an average $\Delta \mathrm{NH}_{\mathrm{x}}$ of $207 \pm 37 \mathrm{nmol} \mathrm{m}^{-3}$, whereas increases during mornings following drier nights $(\mathrm{RH}<0.9)$ were about half that, with an average $94 \pm 16 \mathrm{nmol} \mathrm{m}^{-3}$. Although the RH benchmark of 0.9 only serves as a surrogate for dew formation, this finding does suggest that pools of surface water (i.e. dew or fog), which form on nights that have a high $\mathrm{RH}$, can act as significant $\mathrm{NH}_{\mathrm{x}}$ reservoirs that release $\mathrm{NH}_{3}$ upon evaporation in the mid-morning. This is corroborated by measurements from Burkhardt et al. (2009), who reported an approximate water film thickness of $0.1 \mathrm{~mm}$ during dew events and an average dew $\left[\mathrm{NH}_{4}^{+}\right]$of $3.5 \mathrm{mg} \mathrm{kg}^{-1}$ in a grassland canopy. If all of the $\mathrm{NH}_{4}^{+}$were to be released as $\mathrm{NH}_{3(\mathrm{~g})}$ upon dew evaporation, this reservoir would release about $20 \mu \mathrm{mol} \mathrm{m}^{-2}$ of $\mathrm{NH}_{3(\mathrm{~g})}$ into the atmosphere, which corresponds to an increase of $20 \mathrm{nmol} \mathrm{m}^{-3}$ throughout a $1000 \mathrm{~m}$ boundary layer, equivalent to an increase in mixing ratio of $0.5 \mathrm{ppb}$. Such a release could have a significant impact on near surface $\mathrm{NH}_{3(\mathrm{~g})}$ measurements and manifest itself as a large morning increase of $\mathrm{NH}_{3(\mathrm{~g})}$. The role of dew and fog as a night-time reservoir definitely merits further investigation and could be an important process within this bi-directional framework. Since $\mathrm{NH}_{\mathrm{x}}$ morning increases plateau at $\sim 100 \mathrm{nmol} \mathrm{m}^{-3}$ at an RH below 0.85 , there are likely other contributing factor(s) that lead to this morning enhancement of $\mathrm{NH}_{3}$. Bash et al. (2010) observed a similar morning rise over a fertilized corn field and attributed it to plant and/or soil processes. However, CARE contains significantly less vegetation and is non-fertilized. Walker et al. (2013) suggested surface-air $\mathrm{NH}_{3}$ exchange is impacted by ions that can accumulate in dew as well as the $\mathrm{pH}$ of the dew. In addition, Fig. 4 reveals there are predicted deposition fluxes to the soil during the morning. It is highly unlikely that a substantial rise in $\Gamma_{\text {soil }}$ could occur over the span of a few hours. Stomatal emission cannot be conclusively ruled out as a significant contribution. However, if this were an important factor, one would expect sunrise (when stomata open) and 
the spike to coincide, but given that sunrise at CARE was between 06:00 and 07:15 throughout the campaign, stomatal emission is not likely the driving factor behind this trend at CARE. It is also possible this morning increase is linked to the break-up of the nocturnal boundary layer, as observed by Walker et al. (2006), who measured surface $\mathrm{NH}_{3}$ fluxes over a fertilized soya bean field. Observations from this study rule out soil emissions and suggest that dew/fog evaporation plays a key role in enhancing morning $\mathrm{NH}_{3}$ mixing ratios.

\section{Conclusions}

Measurements of $\Gamma_{\text {soil }}$ and $T_{\text {soil }}$ in a non-fertilized grassland were used to construct a time series of $\chi_{\text {soil }}$ over a 50-day period. $\Gamma_{\text {soil }}$ ranged from 35 to 1850 with an average value of 290 , which is well below the $2000<\Gamma_{\mathrm{g}}<200000$ suggestion by Zhang et al. (2010) for grasslands. Zhang et al. (2010) recommended this range based on field studies exclusively in fertilized grasslands, which is likely the reason $\Gamma_{\mathrm{g}}$ values in this study are lower. Indeed the distinction between fertilization and non-fertilization is critical in accurately assessing bidirectional exchange. Our findings are more in line with the parameterizations of Massad et al. (2010), who suggested a $\Gamma_{\mathrm{g}}$ of 500 for semi-natural, non-fertilized areas without vegetation. Seasonal and diurnal trends in $\chi_{\text {soil }}$ were observed with lower values at night and in September due to decreases in $T_{\text {soil }}$.

Fluxes of $\mathrm{NH}_{3}$ between the soil and atmosphere were estimated using $\left[\mathrm{NH}_{3(\mathrm{~g})}\right]$ measurements and a simple resistance scheme that neglects the influence of vegetation. August fluxes were primarily upwards, except between 07:00-11:00, and resulted in an average emission of $2.6 \pm 4.5 \mathrm{ng} \mathrm{m}^{-2} \mathrm{~s}^{-1}$ from the soil. September was characterized by exclusive deposition from the atmosphere at a rate of $5.8 \pm 3.0 \mathrm{ng}$ $\mathrm{m}^{-2} \mathrm{~s}^{-1}$. These values are fairly similar to fluxes measured by Wichink Kruit et al. (2007), who reported fluxes of 4 and $-24 \mathrm{ng} \mathrm{m}^{-2} \mathrm{~s}^{-1}$ in the summer and autumn, respectively.

HYSPLIT analysis revealed that air masses passing through Toronto were enriched in atmospheric pollutants except $\mathrm{NH}_{3}$. Since CARE lies on a sharp gradient of high emissions to the south and low emission to the north, this lack of directional bias implies that bi-directional exchange efficiently modulates $\mathrm{NH}_{3}$ mixing ratios. Back-of-the-envelope calculations confirm that: (1) the reservoir of $\mathrm{NH}_{4}^{+}$in soil of non-fertilized grasslands is large enough to sustain fluxes to the atmosphere and (2) fluxes are rapid enough to impact surface concentrations on a relevant timescale.

Figure 7 suggests that dew and fog evaporation can enhance the frequently observed morning increase in $\mathrm{NH}_{3}$. It is unlikely that soil emissions contribute to this increase as deposition to the soil is predicted during the morning.

More research is needed to explore seasonal and annual trends in $\Gamma_{\text {soil }}, \Gamma_{\text {stomata, }}$ and $\chi$ canopy across all land types, particularly those lacking in measurements. Since regional- scale models require these parameters as direct inputs, there is great utility in taking a "bottom-up" approach (i.e. measuring $\Gamma$ instead of inferring it from flux data). Even though non-fertilized fields have lower nitrogen content, evidence provided here suggests surface-atmosphere exchange can still affect near-surface concentrations and that this process should be considered when measuring ambient $\mathrm{NH}_{3}$ over non-fertilized surfaces. The role of fog and dew as a nighttime reservoir for water-soluble gases also requires further attention as it may greatly enhance morning $\mathrm{NH}_{3}$ concentrations and is currently not incorporated in models.

Acknowledgements. The AIM-IC was available through support to J. G. Murphy from the Canada Foundation for Innovation and the Ontario Research Fund. G. R. Wentworth and P. K. Gregoire acknowledge funding from the NSERC Integrating Atmospheric Chemistry and Physics from Earth to Space (IACPES) program. The authors are grateful to Environment Canada and the staff at CARE, as well as Greg Evans and Cheol-Heon Jeong for providing a mobile lab to house the instrumentation during the campaign.

Edited by: S. M. Noe

\section{References}

Bash, J. O., Walker, J. T., Katul, G. G., Jones, M. R., Nemitz, E., and Robarge, W. P.: Estimation of in-canopy ammonia sources and sinks in a fertilized Zea mays field., Environ. Sci. Technol., 44, 1683-1689, 2010.

Bash, J. O., Cooter, E. J., Dennis, R. L., Walker, J. T., and Pleim, J. E.: Evaluation of a regional air-quality model with bidirectional $\mathrm{NH}_{3}$ exchange coupled to an agroecosystem model, Biogeosciences, 10, 1635-1645, doi:10.5194/bg-10-1635-2013, 2013.

Bates, R. G. and Pinching, G. D.: Dissociation constant of aqueous ammonia at $0-50{ }^{\circ} \mathrm{C}$ from E.m.f. studies of the ammonium salt of a weak acid, Am. Chem. J., 72, 1393-1396, 1950.

Booth, M. S., Stark, J. M., and Rastetter, E.: Controls on nitrogen cycling in terrestrial ecosystems: a synthetic analysis of literature data, Ecol. Monogr., 75, 139-157, 2005.

Burkhardt, J., Flechard, C. R., Gresens, F., Mattsson, M., Jongejan, P. A. C., Erisman, J. W., Weidinger, T., Meszaros, R., Nemitz, E., and Sutton, M. A.: Modelling the dynamic chemical interactions of atmospheric ammonia with leaf surface wetness in a managed grassland canopy, Biogeosciences, 6, 67-84, doi:10.5194/bg-6-67-2009, 2009.

Bussink, D. W., Harper, L. A., and Corré, W. J.: Ammonia transport in a temperate grassland: II. Diurnal fluctuations in response to weather and management conditions, Agron. J., 86, 621-626, 1996.

Cooter, E. J., Bash, J. O., Walker, J. T., Jones, M. R., and Robarge, W.: Estimation of $\mathrm{NH}_{3}$ bi-directional flux from managed agricultural soils, Atmos. Environ., 44, 2107-2115, 2010.

Cooter, E. J., Bash, J. O., Benson, V., and Ran, L.: Linking agricultural crop management and air quality models for regional 
to national-scale nitrogen assessments, Biogeosciences, 9, 40234035, doi:10.5194/bg-9-4023-2012, 2012.

Dasgupta, P. K. and Dong, S.: Solubility of ammonia in liquid water and generation of trace levels of standard gaseous ammonia, Atmos. Environ., 20, 565-570, 1986.

David, M., Loubet, B., Cellier, P., Mattsson, M., Schjoerring, J. K., Nemitz, E., Roche, R., Riedo, M., and Sutton, M. A.: Ammonia sources and sinks in an intensively managed grassland canopy, Biogeosciences, 6, 1903-1915, doi:10.5194/bg-6-19032009, 2009.

Draxler, R. R. and Rolph, G. D.: HYSPLIT (Hybrid Single-Particle Lagrangian Integrated Trajectory) Model access via NOAA ARL READY Website, available at: http://www.arl.noaa.gov/ HYSPLIT.php (last access: 20 February 2014), NOAA Air Resources Laboratory, College Park, MD, 2014.

Ellis, R. A., Murphy, J. G., Markovic, M. Z., VandenBoer, T. C., Makar, P. A., Brook, J., and Mihele, C.: The influence of gasparticle partitioning and surface-atmosphere exchange on ammonia during BAQS-Met, Atmos. Chem. Phys., 11, 133-145, doi:10.5194/acp-11-133-2011, 2011.

Farquhar, G. D., Firth, P. M., Wetselaar, R., and Weir, B.: On the gaseous exchange of ammonia between leaves and the environment: determination of the ammonia compensation point, Plant Physiol., 66, 710-714, 1980.

Flechard, C. R., Sutton, M. A., and Cape, J. N.: A dynamic chemical model of bi-directional ammonia exchange between seminatural vegetation and the atmosphere, Q. J. Roy. Meteor. Soc., 125, 2611-2641, 1999.

Flechard, C. R., Massad, R.-S., Loubet, B., Personne, E., Simpson, D., Bash, J. O., Cooter, E. J., Nemitz, E., and Sutton, M. A.: Advances in understanding, models and parameterizations of biosphere-atmosphere ammonia exchange, Biogeosciences, 10, 5183-5225, doi:10.5194/bg-10-5183-2013, 2013.

Herrmann, B., Mattsson, M., Jones, S. K., Cellier, P., Milford, C., Sutton, M. A., Schjoerring, J. K., and Neftel, A.: Vertical structure and diurnal variability of ammonia exchange potential within an intensively managed grass canopy, Biogeosciences, 6, 15-23, doi:10.5194/bg-6-15-2009, 2009.

Hicks, B. B., Baldocchi, D. D., Meyers, T. P., Hosker, R. P., and Matt, D. R.: A preliminary multiple resistance routine for deriving dry deposition velocities from measured quantities, Water Air Soil Pollut., 36, 311-330, 1987.

Krupa, S.: Effects of atmospheric ammonia $\left(\mathrm{NH}_{3}\right)$ on terrestrial vegetation: a review, Environ. Pollut., 124, 179-221, 2003.

Li, K., Zhao, Y., Yuan, X., Zhao, H., Wang, Z., Li, S., and Malhi, S. S.: Comparison of factors affecting soil nitrate, nitrogen, and ammonium nitrogen extraction, Commun. Soil Sci. Plant Anal., 43, 571-588, 2012.

Loubet, B., Milford, C., Hill, P. W., Tang, Y. S., Cellier, P., and Sutton, M. A.: Seasonal variability of apoplastic $\mathrm{NH}_{4}^{+}$and $\mathrm{pH}$ in an intensively managed grassland, Plant Soil, 238, 97-110, 2002.

Markovic, M. Z., VandenBoer, T. C., and Murphy, J. G.: Characterization and optimization of an online system for the simultaneous measurement of atmospheric water-soluble constituents in the gas and particle phases, J. Environ. Monit., 14, 1872-1884, 2012.

Massad, R.-S., Nemitz, E., and Sutton, M. A.: Review and parameterisation of bi-directional ammonia exchange between vegeta- tion and the atmosphere, Atmos. Chem. Phys., 10, 10359-10386, doi:10.5194/acp-10-10359-2010, 2010.

Mattsson, M. and Schjoerring, J. K.: Senescence-induced changes in apoplastic and bulk tissue ammonia concentrations of ryegrass leaves, New Phytol., 160, 489-499, 2003.

Mattsson, M., Herrmann, B., David, M., Loubet, B., Riedo, M., Theobald, M. R., Sutton, M. A., Bruhn, D., Neftel, A., and Schjoerring, J. K.: Temporal variability in bioassays of the stomatal ammonia compensation point in relation to plant and soil nitrogen parameters in intensively managed grassland, Biogeosciences, 6, 171-179, doi:10.5194/bg-6-171-2009, 2009.

Milford, C., Theobald, M. R., Nemitz, E., and Sutton, M. A.: Dynamics of ammonia exchange in response to cutting and fertilising in an intensively-managed grassland, Water Air Soil Poll., 1, 167-176, 2001.

Mosquera, J., Hensen, A., Van den Bulk, W. C. M., Vermeulen, A. T., and Erisman, J. W.: Long term $\mathrm{NH}_{3}$ flux measurements above grasslands in the Netherlands, Water Air Soil Poll., 1, 203-212, 2001.

National Pollutant Release Inventory: 2008 Ammonia Emissions for Canada: http://www.ec.gc.ca/inrp-npri/donnees-data/ ap/index.cfm?lang=En (last access: 30 January 2014), 2011.

Nemitz, E., Sutton, M. A., Schjoerring, J. K., Husted, S., and Paul Wyers, G.: Resistance modelling of ammonia exchange over oilseed rape, Agr. Forest Meteorol., 105, 405-425, 2000.

Nemitz, E., Milford, C., and Sutton, M. A.: A two-layer canopy compensation point model for describing bi-directional biosphere-atmosphere exchange of ammonia, Q. J. Roy. Meteor. Soc., 127, 815-833, 2001.

Nemitz, E., Sutton, M. A., Wyers, G. P., and Jongejan, P. A. C.: Gas-particle interactions above a Dutch heathland: I. Surface exchange fluxes of $\mathrm{NH}_{3}, \mathrm{SO}_{2}, \mathrm{HNO}_{3}$ and $\mathrm{HCl}$, Atmos. Chem. Phys., 4, 989-1005, doi:10.5194/acp-4-989-2004, 2004.

Nowak, J. B., Huey, L. G., Russell, A. G., Tian, D., Neuman, J. A., Orsini, D., Sjostedt, S. J., Sullivan, A. P., Tanner, D. J., Weber, R. J., Nenes, A., Edgerton, E., and Fehsenfeld, F. C.: Analysis of urban gas phase ammonia measurements from the 2002 Atlanta Aerosol Nucleation and Real-Time Characterization Experiment (ANARChE), J. Geophys. Res., 111, D17308, doi:10.1029/2006JD007113, 2006.

Personne, E., Loubet, B., Herrmann, B., Mattsson, M., Schjoerring, J. K., Nemitz, E., Sutton, M. A., and Cellier, P.: SURFATMNH3: a model combining the surface energy balance and bidirectional exchanges of ammonia applied at the field scale, Biogeosciences, 6, 1371-1388, doi:10.5194/bg-6-1371-2009, 2009.

Pleim, J. E., Bash, J. O., Walker, J. T., and Cooter, E. J.: Development and evaluation of an ammonia bidirectional flux parameterization for air quality models, J. Geophys. Res. Atmos., 118, 3794-3806, 2013.

Pope, C. A., Burnett, R. T., Thun, M. J., Calle, E. E., Krewski, D., and Thurston, G. D.: Lung cancer, cardiopulmonary mortality, and long-term exposure to fine particulate air pollution, J. Am. Med. Assoc., 287, 1132-1141, 2002.

Reis, S., Pinder, R. W., Zhang, M., Lijie, G., and Sutton, M. A.: Reactive nitrogen in atmospheric emission inventories, Atmos. Chem. Phys., 9, 7657-7677, doi:10.5194/acp-9-7657-2009, 2009.

Rupakheti, M., Leaitch, W. R., Lohmann, U., Hayden, K., Brickell, P., Lu, G., Li, S.-M., Toom-Sauntry, D., Bottenheim, J. W., 
Brook, J. R., Vet, R., Jayne, J. T., and Worsnop, D. R.: An intensive study of the size and composition of submicron atmospheric aerosols at a rural site in Ontario, Canada, Aerosol Sci. Tech., 39, 722-736, 2005.

Schlesinger, W. H. and Hartley, A. E.: A global budget for atmospheric $\mathrm{NH}_{3}$, Biogeochemistry, 15, 191-211, 1992.

Seinfeld, J. H. and Pandis, S. N.: Atmospheric Chemistry and Physics: From Air Pollution to Climate Change, 2nd edn., John Wiley \& Sons, Toronto, 2006.

Spindler, G., Teichmann, U., and Sutton, M. A.: Ammonia dry deposition over grassland - micrometeorlogical flux-gradient measurements and bidirectional flux calculations using an inferential model, Q. J. Roy. Meteor. Soc., 127, 795-814, 2001.

Su, H., Cheng, Y., Oswald, R., Behrendt, T., Trebs, I., Meixner, F. X., Andreae, M. O., Cheng, P., Zhang, Y., and Pöschl, U.: Soil nitrite as a source of atmospheric HONO and OH radicals., Science, 333, 1616-1618, 2011.

Sutton, M. A., Fowler, D., Moncrieff, J. B., and StoretonWest, R. L.: The exchange of atmospheric ammonia with vegetated surfaces, II: Fertilized vegetation, Q. J. Roy. Meteor. Soc., 119, 1047-1070, 1993.

Sutton, M. A., Schjorring, J. K., Wyers, G. P., Duyzer, J. H., Ineson, P., and Powlson, D. S.: Plant-atmosphere exchange of ammonia, Philos. Trans. Phys. Sci. Eng., 351, 261-278, 1995.

Sutton, M. A., Milford, C., Dragosits, U., Place, C. J., Singles, R. J., Smith, R. I., Pitcairn, C. E. R., Fowler, D., Hill, J., ApSimon, H. M., Ross, C., Hill, R., Jarvis, S. C., Pain, B. F., Phillipd, V. C., Harrison, R., Moss, D., Webb, J., Espenhahn, S. E., Lee, D. S., Hornung, M., Ullyett, J., Bull, K. R., Emmett, B. A., Lowe, J., and Wyers, G. P.: Dispersion, deposition and impacts of atmospheric ammonia: quantifying local budgets and spatial variability, Environ. Pollut., 102, 349-361, 1998.

Sutton, M. A., Milford, C., Nemitz, E., Theobald, M. R., Hill, P. W., Fowler, D., Mattsson, M. E., Nielsen, K. H., Husted, S., Erisman, J. W., Otjes, R., Hensen, A., Mosquera, J., Cellier, P., Loubet, B., David, M., Genermont, S., Neftel, A., Blatter, A., Herrmann, B., Jones, S. K., Horvath, L., Führer, E. C., Mantzanas, K., Koukoura, Z., Williams, P., Flynn, M., and Riedo, M.: Biosphere-atmosphere interactions of ammonia with grasslands: experimental strategy and results from a new European initiative, Plant Soil, 228, 131-145, 2001.

Sutton, M. A., Nemitz, E., Milford, C., Campbell, C., Erisman, J. W., Hensen, A., Cellier, P., David, M., Loubet, B., Personne, E., Schjoerring, J. K., Mattsson, M., Dorsey, J. R., Gallagher, M. W., Horvath, L., Weidinger, T., Meszaros, R., Dämmgen, U., Neftel, A., Herrmann, B., Lehman, B. E., Flechard, C., and Burkhardt, J.: Dynamics of ammonia exchange with cut grassland: synthesis of results and conclusions of the GRAMINAE Integrated Experiment, Biogeosciences, 6, 2907-2934, doi:10.5194/bg-6-2907-2009, 2009.
Van Hove, L. W.., Heeres, P., and Bossen, M..: The annual variation in stomatal ammonia compensation point of rye grass (Lolium perenne L.) leaves in an intensively managed grassland, Atmos. Environ., 36, 2965-2977, 2002.

Van Miegroet, H.: Inorganic nitrogen determined by laboratory and field extractions of two forest soils, Soil Sci. Soc. Am. J., 59, 549-553, 1995.

Walker, J. T., Robarge, W. P., Wu, Y., and Meyers, T. P.: Measurement of bi-directional ammonia fluxes over soybean using the modified Bowen-ratio technique, Agr. Forest Meteorol., 138, 54 68, 2006.

Walker, J. T., Jones, M. R., Bash, J. O., Myles, L., Meyers, T., Schwede, D., Herrick, J., Nemitz, E., and Robarge, W.: Processes of ammonia air-surface exchange in a fertilized Zea mays canopy, Biogeosciences, 10, 981-998, doi:10.5194/bg-10-9812013, 2013.

Walker, J. T., Robarge, W. P., and Austin, R.: Modeling of ammonia dry deposition to a pocosin landscape downwind of a large poultry facility, Agric. Ecosyst. Environ., 185, 161-175, 2014.

Wen, D., Zhang, L., Lin, J. C., Vet, R., and Moran, M. D.: An evaluation of ambient ammonia concentrations over southern Ontario simulated with different dry deposition schemes within STILT-Chem v0.8, Geosci. Model Dev. Discuss., 6, 6075-6115, doi:10.5194/gmdd-6-6075-2013, 2013.

Wesely, M. L.: Parameterization of surface resistances to gaseous dry deposition in regional-scale numerical models, Atmos. Environ., 23, 1293-1304, 1989.

Wichink Kruit, R. J., van Pul, W. A. J., Otjes, R. P., Hofschreuder, P., Jacobs, A. F. G., and Holtslag, A. A. M.: Ammonia fluxes and derived canopy compensation points over non-fertilized agricultural grassland in the Netherlands using the new gradient ammonia - high accuracy - monitor (GRAHAM), Atmos. Environ., 41, 1275-1287, 2007.

Wichink Kruit, R. J., van Pul, W. A. J., Sauter, F. J., van den Broek, M., Nemitz, E., Sutton, M. A., Krol, M., and Holtslag, A. A. M.: Modeling the surface-atmosphere exchange of ammonia, Atmos. Environ., 44, 945-957, 2010.

Wichink Kruit, R. J., Schaap, M., Sauter, F. J., van Zanten, M. C., and van Pul, W. A. J.: Modeling the distribution of ammonia across Europe including bi-directional surface-atmosphere exchange, Biogeosciences, 9, 5261-5277, doi:10.5194/bg-9-52612012, 2012.

Wilczak, J. M., Oncley, S. P., and Stage, S. A.: Sonic anemometer tilt correction algorithms, Bound.-Lay. Meteorol., 99, 127-150, 2001.

Zhang, L., Wright, L. P., and Asman, W. A. H.: Bi-directional airsurface exchange of atmospheric ammonia: a review of measurements and a development of a big-leaf model for applications in regional-scale air-quality models, J. Geophys. Res., 115, D20310, doi:10.1029/2009JD013589, 2010. 